ments in the trap, the design of which has been in use since 1963 .

A considerable amount of data on physical factors which may affect salmon migration has been accumulated by the Lancashire River Authority, other fishery boards and university groups. It has been shown, for example, that more fish move upstream during the dark than in the daylight, and they also tond to move more when the air temperature is lower than the water temperature. Mr Stewart's department has also been getting interesting information on the mean water level in rivers necessary for migratory fish which apparently need deeper water than non-migratory fish. They have found, for example, that in the upper reaches of the Lune 26 miles from its mouth, and in the Leven only to0 yards from tidal waters, salmon require a very similar mean water level. In other words, the fish appear to need the same water level in estuaries and at the head waters of a river. It is obviously important to know the minimum water level tolerated by migratory fish, for then it can be judged how much water can be extracted from salmon rivers for urban and industrial purposes. The fishing value of the Lune is well over $£ 1$ million, so that more than just the pleasure of the local angler is at stake. The computer analysis is also expected to help in other directions. It may show, for example, how the number of fish in British rivers is being affected by netting salmon off Greenland.

\section{Fertile London Zoo}

$1 \times 1967$, for the third year running, attendances at the London Zoo exceeded two million. The council of the Zoological Society of London in its annual report attributes the high attendance to the attraction of the new buildings, to the general improvement of the exhibition and facilities for visitors and to an extensive advertising campaign and wide press publicity. At Thipsnade, the attendance of 588,825 was less than

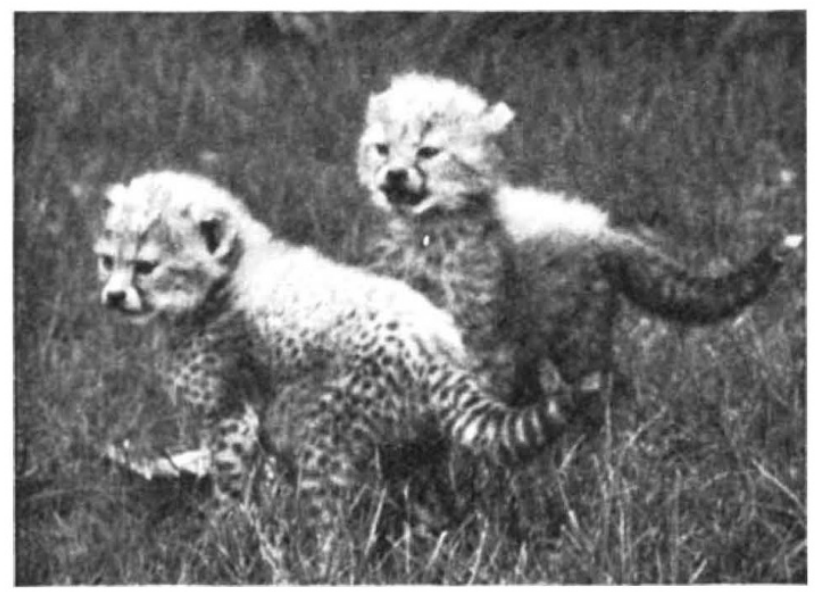

Two of the cheetah cubs born at Whipsnade in September.

in 1966, but the wet weather in May was probably partly responsible for the decrease.

Rebuilding at Regent's Park and improvements at Whipsnade continue to make heavy demands on the society's financial resources. Capital expenditure during the year was $£ 233,000$. The accounts for the vear show a small deficit, but the council has decided not to increase the entrance charges for 1968. The
Charles Clore Pavilion for mammals, opened last year, is said to have been a great success, but its popularity with visitors has brought some unforeseen difficulties, in particular the problems of noise and crowd control in the nocturnal section. Other works in progress are reported - the new combined sea-lion viewing stand and canine quarters building postponed from 1966 should be finished this summer.

The socicty is concerned to co-operate with other zoos in breeding projects. Its efforts on behalf of Chi-Chi, the giant panda, are well known. During 1967 its male snow leopard was sent to Amsterdam Zoo where there is a single female of this comparatively rare species. The chief breeding success of the year at Whipsnade was the birth in September of three cheetahs. The cubs, one male and two females, were left in their enclosure with their mother who has reared them entirely herself. This is the first time in Britain that cheetahs have been bred successfully and it is probably only the second time that cheetah cubs born in captivity have been reared by their mother.

Details are given of the society's scientific activities and research projects. The staff of the Nuffield Institute of Comparative Medicine now numbers 47. During the year the institute was designated by the World Health Organization as a collaborating centre for comparative pathology of non-domesticated vertebrates. Research at the institute included studies on viral and filarial disease in New World monkeys, trypanosomiasis, and nutrition in primates. Projects at the Wellcome Institute of Comparative Physiology included work on the reproductive cycle of the Skomer vole, problems of infertility in captive animals and reproduction in the chinchilla. The society's educational programme for schools seems also to have been a success - the number of pupils attending lecture. demonstrations increased by about 18 per cent over the figure for 1966. Membership of the Young Zoologists Club has also increased.

\section{Disease caused by Transfusion}

A RECEnT study undertaken by Allan G. Redeker and Carl E. Hopkins of the University of Southern California School of Medicine and the Los Angeles County Hospital has shown that whole pooled serum often transmits the virus causing hepatitis. Out of 120 patients studied over a period of three years, twelve contracted acute hepatitis within six months of receiving whole pooled serum, but not a single case occurred among patients receiving a control solution of five per cent serum albumin. The severity of this finding is further emphasized by the fact that the pooled serum in each case had been subjected to the method of sterilization normally used in the United Statesstorage for six months at room temperature followed by treatment with ultraviolet irradiation.

Pooling - the mixing of large quantities of plasma from the blood of many individuals-is used on a large scale in the United States, and it has been estimated that more than 300,000 units are administered annually. Serum is used primarily for severe burns and for transfusing to patients while they are waiting for their blood to be cross-matched. It was used extensively during the Second World War to revive and sustain the badly wounded. In view of 